\title{
Human Health Implications of Omega-3 and Omega-6 Fatty Acids in Blubber of the Bowhead Whale (Balaena mysticetus)
}

\author{
JOHN E. REYNOLDS, III, ${ }^{1}$ DANA L. WETZEL ${ }^{1}$ and TODD M. O'HARA ${ }^{2}$
}

(Received 28 March 2005; accepted in revised form 26 August 2005)

\begin{abstract}
Concerns exist regarding the health and nutrition of subsistence-based communities in Alaska. An apparent increase in diabetes, heart disease, obesity, and other disease conditions among Alaska Natives has accompanied their change from a traditional diet to a more "Western" diet. In northern Alaska, the meat, maktak (epidermis and blubber), and other products of bowhead whales provide important components of Native diets. This study assessed the fatty acid constituents of bowhead whale blubber to evaluate their possible health benefits. Working with hunters in Barrow, Alaska, we acquired samples for chemical analysis from five blubber depths at each of six body locations. We used gas chromatography-mass spectrometry of fatty-acid picolinyl esters to confirm the fatty-acid composition of samples. Analyses indicated that bowhead blubber contains relatively high levels of omega-3 fatty acids and that, on average, blubber samples from sites at the umbilical girth contain more omega3 fatty acids than do samples from a girth $1 \mathrm{~m}$ caudal to the blowhole (roughly at the axillary girth). Omega-6 fatty acids were rare or undetectable in all samples. Omega-3 fatty acids have been suggested or shown to be important in the treatment or prevention of many diseases, including elevated blood pressure and cholesterol, heart disease, stroke, diabetes, arthritis, depression, and some cancers. Beyond the cultural benefits associated with subsistence hunting of bowhead whales, consumption of bowhead whale blubber provides some important health and nutritional benefits.
\end{abstract}

Key words: blubber, bowhead whale, diet, fatty acids, health, omega-3, omega-6

RÉSUMÉ. Il existe des inquiétudes quant à la santé et à l'alimentation des collectivités basées sur la subsistance en Alaska. L'augmentation apparente du diabète, des maladies cardiaques, des cas d'obésité et d'autres maladies chez les Autochtones de l'Alaska va de pair avec leur passage d'un régime alimentaire traditionnel à un régime plus « occidental ». Dans le nord de l'Alaska, la viande, maktak (épiderme et petit lard), et d'autres produits de la baleine boréale représentent d'importantes composantes du régime alimentaire des Autochtones. Dans le cadre de cette étude, nous nous sommes penchés sur les composants en acides gras du petit lard de la baleine boréale et ce, afin de déterminer leurs bienfaits possibles sur la santé. De concert avec des chasseurs de Barrow, en Alaska, nous avons prélevé des échantillons de cinq épaisseurs de petit lard provenant de chacun de six endroits différents du corps afin d'en faire l'analyse chimique. Nous avons utilisé la chromatographie en phase gazeuse et la spectrométrie de masse d'esters picoliniques d'acides gras pour confirmer la composition en acides gras des échantillons. Les analyses laissaient supposer que le petit lard de la baleine boréale a une teneur relativement élevée en acides gras oméga-3 et, qu'en moyenne, les échantillons de petit lard provenant des endroits situés à la hauteur ombilicale renferment de plus grandes quantités d'acides gras oméga-3 que les échantillons provenant d'un endroit situé $1 \mathrm{~m}$ de la queue jusqu'à l'évent (environ à la hauteur axillaire). Dans tous les échantillons, les acides gras oméga-6 se faisaient rares, voire même indécelables. Certaines recherches portent à croire ou démontrent que les acides gras oméga-3 jouent un rôle important dans le traitement ou la prévention de nombreuses maladies, dont l'hypertension artérielle, le taux de cholestérol élevé, les maladies du cœur, les accidents cérébrovasculaires, le diabète, l'arthrite, la dépression et certains cancers. En plus des avantages culturels liés à la chasse de subsistance de la baleine boréale, la consommation du petit lard de la baleine boréale présente d'importants avantages du point de vue de la santé et de l'alimentation.

Mots clés : petit lard, baleine boréale, régime alimentaire, acides gras, santé, oméga-3, oméga-6

Traduit pour la revue Arctic par Nicole Giguère.

\section{INTRODUCTION}

The benefits of a subsistence lifestyle for Alaska Natives have been described by a number of authors (Egeland et al., 1998; Hild, 2002; Arnold and Middaugh, 2004;
Verbrugge and Middaugh, 2004). Those benefits include facilitating self-definition and self-determination, maintaining communities as close-knit entities, providing economic gain, and promoting good nutrition and health. Concern regarding the presence and levels of anthropo-

\footnotetext{
${ }^{1}$ Mote Marine Laboratory, 1600 Thompson Parkway, Sarasota, Florida 34236, U.S.A.; Reynolds@ mote.org

${ }^{2}$ Department of Wildlife Management, North Slope Borough, Barrow, Alaska 99728; current address: Institute of Arctic Biology, P.O. Box 757000, University of Alaska Fairbanks, Fairbanks, Alaska 99775-7000, U.S.A.

(C) The Arctic Institute of North America
} 
genic contaminants in subsistence harvested food has caused some individuals and communities to reduce consumption of traditional foods that have pronounced health benefits (Egeland et al., 1998; Arnold and Middaugh, 2004; Verbrugge and Middaugh, 2004). At the Tenth International Congress on Circumpolar Health in 1996, elders suggested that fear of contaminated food may precipitate dietary changes that are more harmful than the contaminants themselves (Egeland et al., 1998). Traditional diets high in marine mammals and fish have historically been suggested to reduce the likelihood of cardiovascular disease (heart attacks and strokes), diabetes, and other adverse health conditions in Alaska Natives, while recent changes in dietary preferences have been associated with increased prevalence of these diseases in some Native communities (e.g., Nobmann et al., 1992; Egeland et al., 1998; Hild, 2002; McLaughlin et al., 2004). The extent to which Inuit subsistence diets actually contribute to reducing the risk of heart disease and stroke has recently been questioned (Bjerregaard et al., 2003).

The traditional diet of Alaska Natives is generally high in protein, low in saturated fatty acids, and high in omega3 fatty acids, which are polyunsaturated (Eaton and Konner, 1985; Egeland et al., 1998; Nobmann et al., 1998, 1999, 2005). A more "Western" diet, in contrast, has higher levels of saturated fatty acids, lower levels of unsaturated fatty acids, and higher levels of omega- 6 fatty acids. Gurr (1999:148) indicates that a diet with a high omega-6:omega3 ratio is associated with certain disease states and that an appropriate balance (yet to be determined) has "implications for future diets and food."

The proper intake of fatty acids is essential for good health in humans. There are more than 1000 naturally occurring fatty acids (Gunstone, 1994). Gurr (1999) notes that some ambiguity exists regarding what is meant by "essential fatty acids." Gunstone and Herslöf (2000:75) define the term as "polyunsaturated fatty acids of the (n-6) and (n-3) families which are essential for life and good health," adding that "they cannot be biosynthesized by animals and they (or some suitable precursor) must be obtained from plant sources as part of the diet." This strict definition accords with the more generic one (nutrients that are needed but cannot be adequately provided by the body) given by Gurr (1999) and suggests that only two fatty acids-linoleic and alpha-linolenic_are truly "essential." It is clear, however, that a healthy human diet should preferentially include or restrict intake of certain other fatty acids or classes of fatty acids as well (Krauss et al., 2000). Bowhead whale (Balaena mysticetus) blubber contains at least traces of 45 fatty acids (Wetzel and Reynolds, 2004), including several that have been suggested to be beneficial for human health (see, for example, Nobmann et al., 1999; Kris-Etherton et al., 2002).

Some omega-3 fatty acids have been suggested or shown to be beneficial in the prevention or treatment of a number of disease conditions, including high cholesterol, high blood pressure, heart disease, stroke, diabetes, arthritis, depression, schizophrenia, attention deficit/hyperactivity disorder, inflammatory bowel disease, asthma, macular degeneration, and colon, breast, and prostate cancer (Storien et al., 1991; Egeland et al., 1998; Gurr, 1999; Kris-Etherton et al., 2002; Li et al., 2003). Appropriate levels of omega3 fatty acids in the diet are also important for healthy pregnancy and proper neonatal growth and development (Lanting et al., 1994; Egeland et al., 1998; Martinez et al., 1998).

The U.S. Food and Drug Administration (FDA) has found that not all of the scientific evidence for multiple therapeutic benefits of omega- 3 fatty acids is conclusive, but it is suggestive for reductions in heart disease (FDA, 2004). The Agency for Healthcare Research and Quality (AHRQ) assessed research evidence and noted that the benefits of omega-3 fatty acids varied for a variety of disease conditions; in some cases, however, the data were insufficient for drawing conclusions (MacLean et al., 2004). Nonetheless, peer-reviewed studies provide good evidence of health benefits of omega-3 fatty acids for conditions such as diabetes (Kris-Etherton et al., 2002) and heart disease (Li et al., 2003). In fact, numerous studies (Bang et al., 1976; Bang and Dyerberg, 1980; Dyerberg, 1989; Nobmann et al., 1999; Kris-Etherton et al., 2002) have linked omega-3 fatty acids with reductions in heart disease in general, and specifically to low incidence of heart disease and other beneficial effects in Greenland Eskimos or Siberian Yupiks in Alaska.

The most important dietary omega-3 fatty acids include alpha-linolenic acid (ALA), eicosapentaenoic acid (EPA), and docosahexaenoic acid (DHA). For most people, the primary sources of omega-3 fatty acids include oils from fatty, cold-water fish such as salmon, halibut, and sardine, which contain EPA and DHA, and oils from plants such as flaxseed, canola, soybean, and walnut, which contain ALA. The FDA has not published recommended daily allowances (also referred to as Dietary Reference Intakes or DRIs) for omega-3 fatty acids, but other groups have. For example, the Institute of Medicine and National Academy of Sciences suggest including between $1.3 \mathrm{~g}$ and $2.7 \mathrm{~g}$ of omega-3 fatty acids in a 2000 kcal daily diet (National Academy of Sciences, 2002). Li et al. (2003) report that recommended intakes for omega-3 fatty acids range from about $215 \mathrm{mg} /$ day (UK Department of Health, 1991) to $1250 \mathrm{mg} /$ day (British Nutrition Foundation, 1992). The World Health Organization and North Atlantic Treaty Organization have made formal, population-based recommendations: for EPA plus DHA, daily recommended amounts range from 300 to $500 \mathrm{mg} / \mathrm{day}$, and for ALA, the range is $800-1100 \mathrm{mg} /$ day (Kris-Etherton et al., 2002), a cumulative amount comparable to that recommended by the National Academy of Sciences (2002) above. The EPA plus DHA can be acquired by consuming two to three servings of fatty fish per week or by taking fish oil supplements. Since ALA becomes converted internally to EPA and DHA, people on diets low in plant oils (such as the traditional diet of Inupiat and other Alaska Natives) 


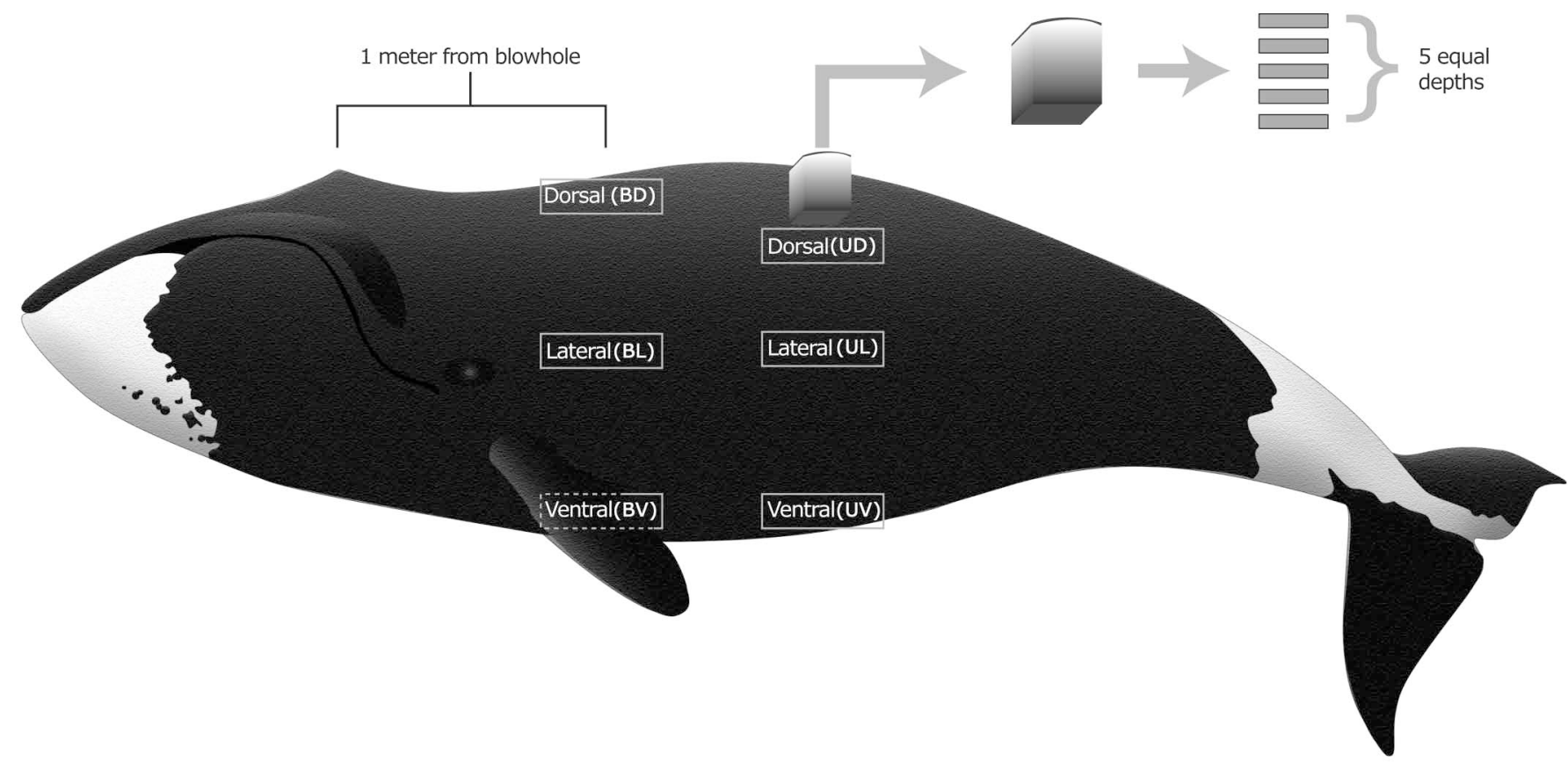

FIG. 1. Bowhead whale sampling sites and the division of a full-thickness sample into five equal layers. Illustration by Lawson Mitchell, based on an original illustration by Pieter Arend Folkens/Alaska Whale Foundation, subsequently modified by Mau (2004) and Willetto et al. (2002).

would need to consume greater amounts of the other beneficial omega-3 fatty acids. It is noteworthy that excessive intake of omega-3 fatty acids (over about $3000 \mathrm{mg} /$ day; Kris-Etherton et al., 2002) may lead to health problems (Egeland et al., 1998).

In this paper, we evaluate the presence and relative abundance of omega- 3 and omega- 6 fatty acids in the blubber of the bowhead whale. This information should prove useful to subsistence-based communities that harvest and consume this species. Such communities must weigh the relative costs and benefits of continuing to consume a traditional diet in light of known and perceived contamination in the Arctic, and the results of this study provide data that will help inform that decision.

\section{MATERIALS AND METHODS}

\section{Sample Acquisition}

With the permission and cooperation of Inupiat whaling captains in Barrow, Alaska, scientists acquired tissue samples for archival and analysis. The specimens examined for this study were collected from bowhead whale 98B23, a sub-adult male measuring $11.7 \mathrm{~m}$ in length.

We acquired and examined 29 blubber samples from six body locations (Fig. 1): dorsal (BD), lateral (BL), and ventral (BV) sites $1 \mathrm{~m}$ caudal to the blowhole, and dorsal (UD), lateral (UL), and ventral (UV) sites at the level of the umbilicus. The samples represented five blubber depths from each site except BD, where only four of five depths were sampled.
To minimize oxidative or other changes to constituents, blubber samples originally collected during the fall 1998 bowhead hunt in Barrow were frozen (in Barrow at $-20^{\circ} \mathrm{C}$; at University of Alaska, Fairbanks, at $-80^{\circ} \mathrm{C}$ ) in separate, sealed plastic bags. In November 2001, the samples archived in Fairbanks were sub-sampled for this study, which used a 5-10 g sub-sample removed from the center of each whole sample. The sub-samples were placed in clean glass jars with Teflon lids and shipped frozen to Mote Marine Laboratory (Sarasota, Florida) for analysis. Each sample was labeled with a location code (BD, BL, etc.) and a depth code (1-5, with 1 representing the most superficial $(0-20 \%)$ depth sample and 5 representing the $80-100 \%$ depth sample).

\section{Chemical Analyses}

The analyses of the bowhead blubber involved esterification of bowhead blubber to form fatty acid nitrogen (picolinyl) esters (Wetzel and Reynolds, 2004). The technique allows optimal resolution of fatty acid constituents in the samples.

Approximately $1.0 \mathrm{~g}$ of blubber was extracted using a modified Folch extraction (Folch et al., 1957), with butylated hydroxytoluene (BHT) added as an antioxidant. Picolinyl ester derivatives were prepared via a modified Destaillats and Angers method (Destaillats and Angers, 2002; Wetzel and Reynolds, 2004). Whole lipid was added to a homogenized mixture of 3-hydroxymethylpyridine and a solution of potassium tert-butoxide in tetrahydrofuran. The lipid mixture was then incubated at $45^{\circ} \mathrm{C}$ for 30 minutes. The organic phase was washed with a $2.5 \%$ 
sodium bicarbonate solution, collected, dried over anhydrous sodium sulfate, and evaporated under a stream of nitrogen. The sample was redissolved in hexane. Further purification of the extracts used a Florisil ${ }^{\mathrm{TM}}$ column to eliminate ancillary compounds that have the potential to co-elute with fatty acids.

All samples were analyzed by a Thermo-Finnigan Polaris Q gas chromatograph-mass spectrometer (GC-MS), equipped with a DB5 fused silica capillary column (30 m $\times 0.25$ i.d.) with helium as the carrier gas. The mass spectrometer was scanned from mass 50 to 500 in $0.5 \mathrm{sec}$ at an ionization potential of $70 \mathrm{eV}$. The program rate for the picolinyl ester analysis began at $80^{\circ} \mathrm{C}$ for $2 \mathrm{~min}$., increased from $80^{\circ} \mathrm{C}$ to $185^{\circ} \mathrm{C}$ at $7^{\circ} \mathrm{C} \mathrm{min}{ }^{-1}$, held for $5 \mathrm{~min}$., then from $185^{\circ} \mathrm{C}$ to $260^{\circ} \mathrm{C}$ at $5^{\circ} \mathrm{C} \mathrm{min}^{-1}$, held for $5 \mathrm{~min}$., from $260^{\circ} \mathrm{C}$ to $325^{\circ} \mathrm{C}$ at $5^{\circ} \mathrm{C} \mathrm{min}{ }^{-1}$, and held for $10 \mathrm{~min}$.

\section{RESULTS}

The percent compositions (of total extractable lipid) of omega-3 fatty acids for the various samples appear in Table 1. Five different omega-3 fatty acids-18:4(n-3); $20: 5(n-3)$ or eicosapentaenoic acid (EPA); 21:5(n-3); 22:5(n-3) or docosapentaenoic acid (DPA); and 22:6(n-3) or docosahexaenoic acid (DHA) - represented major components (1.0\% composition or more) of at least one blubber sample. Collectively these five omega- 3 fatty acids represented more than $10 \%$ (percent composition) of all fatty acids present in $25 \%$ of the samples analyzed (see Table 1; range of all omega-3 fatty acids per sample = $1.70-16.43 \%$; overall mean for all samples $=8.83 \%$ ). Eicosapentaenoic acid, the most prevalent omega-3 fatty acid, was found in every blubber sample. High EPA levels occurred in a number of samples at various locations and blubber depths (Table 1).

On average, the samples taken from a girth one meter caudal to the blowhole had a statistically smaller percent composition of omega-3 fatty acids (Table 1 ; mean = $7.41 \%$; $\mathrm{SD}=4.58$ ) than did samples taken from the umbilical girth (mean $=10.14 \% ; \mathrm{SD}=2.16$; t-test: $p=0.0472$ ). These differences in omega-3 fatty acid levels in samples from the different girths are illustrated in Figure 2.

The distribution and relative prevalence of the individual omega-3 and omega- 6 fatty acids are shown in Figure 3. Eicosapentaenoic acid (EPA) is found in relatively high amounts (1.70\% to $10.98 \%$ composition) at all sample sites. DHA and DPA are both found in modest to high amounts in most ( 9 of 15) samples from sites at the blowhole girth and in all samples from umbilical sites. The other reasonably common omega-3 fatty acid, 18:4(n-3), is found exclusively in samples from umbilical sites. These combined distributions contribute to the umbilical girth sites' being generally richer in omega- 3 fatty acids than the sites at the girth 1 meter caudal to the blowhole.

Conversely, the omega- 6 fatty acids, 15:1(n-6) and 20:4(n-6) (arachidonic acid), were generally undetectable and represented only minor components of four of 20 samples (Table 1).

\section{DISCUSSION}

The results of our analysis are based on detailed examination of samples from a single individual bowhead whale; thus, they may or may not apply well to bowhead whales in general. For example, it is impossible from our study to assess the extent to which gender, age, or season (i.e., animals taken during the spring hunt vs. those taken during the fall hunt) may affect fatty acid composition of blubber. We have not replicated these rather costly analyses with other whales to confirm the fatty acid constituents of their blubber in the three-dimensional manner we employed. Nonetheless, to the hunters and scientists (including a veterinarian) present, the whale from which samples were taken appeared to be a healthy animal representative of "normal" landed bowhead whales. It should also be recognized that analysis of fatty acids for foraging studies is commonly done (e.g., Iverson et al., 1997) with the assumption that specific prey species have a particular "signature" that is relatively common to all individuals of that species. In other words, especially for highly specialized feeders (such as bowhead whales) and organisms at lower trophic levels (including bowhead whales), fatty acid constituents are assumed not to vary much among individuals of a particular species. Even for predators with complex foraging strategies (e.g., bottlenose dolphins, Tursiops truncatus) the general fatty acid profile for adult animals in a particular year and geographic location is similar (Wetzel et al., unpubl.). Thus, even though our information is from a single individual, it is likely to be at least somewhat representative of the species and of other individuals consumed by northern communities.

The fatty acid constituents of bowhead whale blubber confer important nutritional benefits on subsistence consumers. The relatively low percentage of saturated fatty acids $(7.97 \%$ to $27.25 \%$ composition for different blubber samples; Wetzel et al., unpubl. data) may relate functionally to maintaining a fluid state for the outer layers of blubber in extremely cold $\left(<0^{\circ} \mathrm{C}\right.$ seasonally) Arctic waters, but incidentally it is consistent with recommendations for a healthy diet for people. The percentage of fatty acid classes in different blubber samples is quite variable, ranging from $57.93 \%$ to $80.48 \%$ for monounsaturated and from $2.8 \%$ to $18.86 \%$ for polyunsaturated fatty acids (Wetzel et al., unpubl. data).

The high amounts (range $=1.70 \%$ to $16.43 \%$ composition; mean $=8.83 \%$ ) of omega- 3 fatty acids are also consistent with recommendations for a healthy diet. Specifically recommended for an adult are approximately $300-500 \mathrm{mg} /$ day of EPA plus DHA (Kris-Etherton et al., 2002). These are, by far, the most abundant omega-3 fatty acids in bowhead whale blubber (Table 1), and EPA ranks among the most prevalent fatty acids of any type in the 
TABLE 1. Percent composition (i.e., percent of total extractable lipids) of omega-3 fatty acids and omega-6 fatty acids in bowhead whale blubber samples. Sample locations are indicated by site and layer and described in Methods. ND indicates that presence of a particular fatty acid could not be detected by the gas chromatograph-mass spectrometer. For calculations of means and standard deviations, a value of zero was used for ND. Fatty acids listed in bold are especially beneficial for human nutrition.

\begin{tabular}{|c|c|c|c|c|c|c|c|c|}
\hline \multirow[b]{2}{*}{ Site/Layer } & \multicolumn{6}{|c|}{ Omega-3 } & \multicolumn{2}{|c|}{ Omega-6 } \\
\hline & 18:4(n3) & $\begin{array}{c}20: 5(n-3) \\
(\text { EPA })\end{array}$ & $21: 5(n-3)$ & $\begin{array}{c}\text { 22:5(n-3) } \\
\text { (DPA) }\end{array}$ & $\begin{array}{c}\text { 22:6(n-3) } \\
\text { (DHA) }\end{array}$ & $\begin{array}{c}\text { Total } \\
\text { Omega-3 }\end{array}$ & $15: 1(n-6)$ & $20: 4(n-6)$ \\
\hline BD2 & ND & 5.44 & ND & 0.81 & 1.65 & 7.90 & Trace & ND \\
\hline BD3 & ND & 7.52 & ND & 1.16 & 1.68 & 10.36 & ND & ND \\
\hline BD4 & ND & 4.72 & ND & 0.70 & 0.87 & 6.28 & ND & ND \\
\hline BD5 & ND & 5.63 & ND & ND & ND & 5.63 & ND & ND \\
\hline BL1 & ND & 2.81 & ND & ND & ND & 2.81 & ND & ND \\
\hline BL2 & ND & 5.76 & ND & 1.08 & 1.08 & 7.52 & ND & ND \\
\hline BL3 & ND & 8.74 & ND & 2.72 & 2.72 & 12.64 & ND & ND \\
\hline BL4 & ND & 5.10 & ND & ND & ND & 5.10 & ND & ND \\
\hline BL5 & ND & 8.37 & 0.31 & 0.31 & 3.74 & 14.04 & Trace & 0.24 \\
\hline BV1 & ND & 2.12 & ND & ND & ND & 2.12 & ND & ND \\
\hline BV2 & ND & 1.70 & ND & ND & ND & 1.70 & ND & ND \\
\hline BV3 & ND & 2.45 & ND & 0.23 & 0.39 & 3.07 & ND & ND \\
\hline BV4 & ND & 5.87 & ND & 0.87 & 1.43 & 8.17 & ND & ND \\
\hline BV5 & ND & 10.98 & ND & 1.64 & 3.81 & 16.43 & ND & ND \\
\hline Mean B & & 5.52 & 0.02 & 0.63 & 1.24 & 7.41 & (Trace) & 0.02 \\
\hline SD B & & 2.72 & 0.08 & 0.61 & 1.36 & 4.58 & & 0.06 \\
\hline UD1 & 1.25 & 9.26 & ND & 0.99 & 2.08 & 13.58 & ND & 0.25 \\
\hline UD2 & 0.47 & 4.07 & ND & 0.54 & 0.84 & 5.93 & ND & 0.37 \\
\hline UD3 & 0.48 & 5.40 & ND & 0.72 & 0.97 & 7.58 & ND & ND \\
\hline UD4 & 0.48 & 5.43 & ND & 0.72 & 0.98 & 7.62 & ND & ND \\
\hline UD5 & 0.76 & 4.67 & ND & 1.11 & 1.65 & 8.18 & ND & ND \\
\hline UL1 & 0.76 & 7.46 & ND & 0.91 & 1.73 & 10.87 & ND & 0.20 \\
\hline UL2 & 0.45 & 6.96 & ND & 1.53 & 1.37 & 10.32 & ND & ND \\
\hline UL3 & 0.37 & 6.63 & ND & 1.85 & 1.58 & 10.44 & ND & ND \\
\hline UL4 & ND & 7.35 & ND & 2.05 & 1.69 & 11.09 & ND & ND \\
\hline UL5 & ND & 5.79 & ND & 1.97 & 1.56 & 9.32 & ND & ND \\
\hline UV1 & 0.43 & 7.47 & ND & 1.67 & 1.84 & 11.42 & ND & ND \\
\hline UV2 & 0.44 & 7.22 & ND & 1.55 & 1.55 & 10.76 & ND & ND \\
\hline UV3 & 0.39 & 5.97 & ND & 1.87 & 1.51 & 9.75 & ND & ND \\
\hline UV4 & 0.60 & 7.26 & ND & 1.51 & 2.39 & 11.75 & ND & ND \\
\hline UV5 & 0.46 & 9.80 & ND & 1.87 & 1.45 & 13.58 & ND & ND \\
\hline Mean U & 0.49 & 6.72 & & 1.39 & 1.55 & 10.14 & & 0.05 \\
\hline SD U & 0.22 & 1.44 & & 0.52 & 0.39 & 2.16 & & 0.11 \\
\hline Overall Mean & 0.25 & 6.14 & 0.01 & 1.03 & 1.40 & 8.83 & (Trace) & 0.04 \\
\hline Overall SD & 0.33 & 2.24 & 0.06 & 0.67 & 0.98 & 3.74 & & 0.10 \\
\hline
\end{tabular}

blubber (Wetzel et al., unpubl. data). Interestingly, EPA is found at every blubber sample site, whereas the distribution of DHA and DPA (the other relatively abundant omega-3s) is skewed toward the umbilical sites.

Unlike the omega- 3 fatty acids, the omega- 6 fatty acids are either very minor components of whale blubber samples, or are undetectable. In whale blubber, the ratio of omega- 3 to omega- 6 fatty acids is on the order of several hundred to one. Since approximately a 1:10 ratio of these compounds is recommended (National Academy of Sciences, 2002), the omega-6 fatty acids in Inupiat diets would have to come from other sources, possibly even untested sources (such as meat) from the bowhead itself.

The majority of bowhead blubber $(77 \%$, on average, but dependent on location) is lipid (Mau, 2004), and most $(93.9-100 \%)$ of the lipid in bowhead blubber is in the form of triglycerides (O'Hara et al., 2001), molecules containing three fatty acids attached to a small glycerol backbone. If one assumes that a) a representative piece of bowhead whale blubber is $95 \%$ triglyceride; b) triglyceride is $95 \%$ fatty acids; and c) EPA and DHA (combined) represent approximately $9 \%$, on average, of the fatty acids present in bowhead blubber (from Table 1), then one can estimate the mass of omega- 3 fatty acids in a blubber sample. For example, $1 \mathrm{~g}$ of blubber (i.e., the same mass as a single packet of artificial sweetener) would contain approximately $63 \mathrm{mg}$ of essential omega-3 fatty acids $(0.77 \times 0.95 \times 0.95 \times 0.09 \times 1=0.063 \mathrm{~g})$. Thus, consumption of $10 \mathrm{~g}$ of bowhead whale blubber provides, on average, $630 \mathrm{mg}$ of omega- 3 fatty acids and satisfies the recommended daily allowance (up to $500-800 \mathrm{mg}$ ) of EPA plus DHA for adults (recalling that ALA comes from plant sources). The amount of EPA plus DHA in $10 \mathrm{~g}$ of blubber is comparable to the amounts found in a $3 \mathrm{oz}$ (or $85 \mathrm{~g}$ ) portion of some salmon (Kris-Etherton et al., 2002). For comparison, a $3 \mathrm{oz}$ portion of bowhead blubber would 


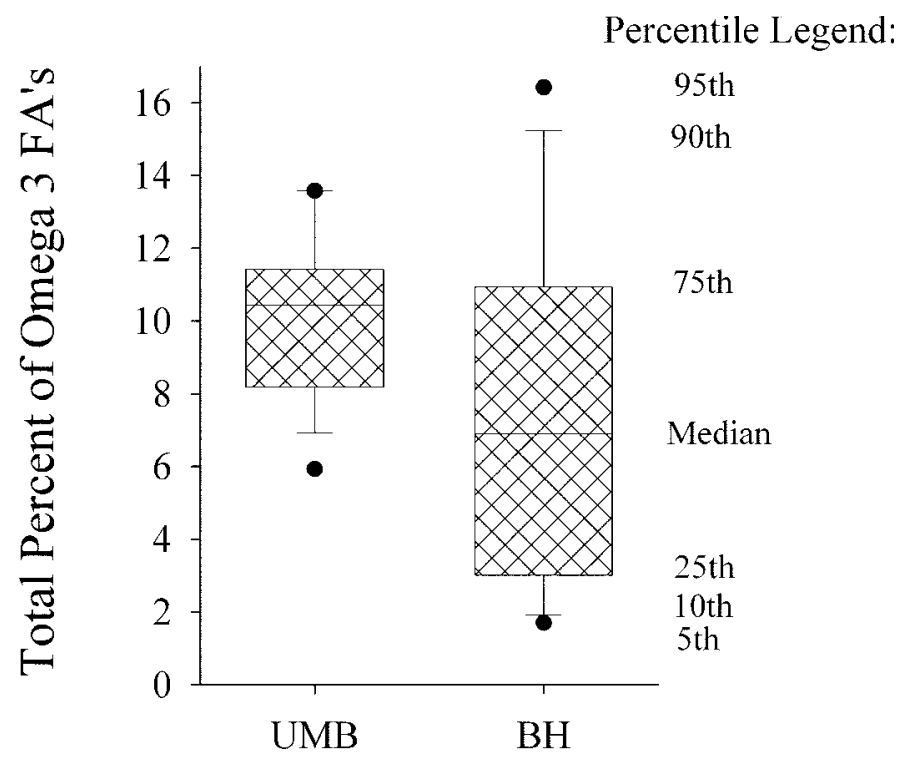

FIG. 2. The percent composition of all omega- 3 fatty acids for samples taken from locations at the umbilical girth (UMB) and from a girth 1 meter caudal to the blowhole $(\mathrm{BH})$.

contain $5355 \mathrm{mg}(=5.355 \mathrm{~g})$ of EPA plus DHA, or 7-10 times the recommended daily allowance.

Is $10 \mathrm{~g}$ per person per day a realistic amount of blubber for Inupiat communities to consume? When a bowhead whale is harvested, tens or hundreds of people participate in the butchering and distribution of meat and blubber. A delicacy that is distributed to warm and nourish the participants during this process is called unalik (boiled maktak, or epidermis and associated blubber). Many pieces of unalik that are consumed well exceed $10 \mathrm{~g}$ in weight, and it would not be unusual for a person to consume several pieces while a whale is being processed.

Thus, it is possible that a person could consume substantially more blubber than 10 grams in a given day. Egeland et al. (1998) noted that excessive intake (defined by Kris-Etherton et al., 2002 as amounts over $3 \mathrm{~g}$ /day) of omega-3 fatty acids may potentially produce some negative health consequences (e.g., immune system suppression or prolonged bleeding during traumatic injuries). Interestingly, Nobmann et al. (2005) found that among some groups of Eskimos in northwest Alaska, men consumed an average of up to $6.8 \mathrm{~g}$ of omega- 3 fatty acids per day, and women as much as $6.5 \mathrm{~g} / \mathrm{day}$. This amount exceeds the threshold of "excessive" noted by Kris-Etherton et al. (2002) but correlates well with our results regarding the amount of omega- 3 fatty acids that would be consumed by eating a single 3 -oz portion of bowhead whale blubber containing, on average, $5.4 \mathrm{~g}$ of omega- 3 fatty acids.

From the available research, we are aware of no evidence of human health problems associated with Alaskan Native consumption of high amounts of omega-3 fatty acids, whereas, as noted above, numerous studies have correlated a variety of disease conditions with insufficient omega-3 fatty acid intake. The National Academy of Sciences (2002) indicates that consumption of 1.3-2.7 $\mathrm{g}$ of omega- 3 fatty acids is appropriate given a daily energy intake of $2000 \mathrm{kcal}$. For people leading a physically active lifestyle (including subsistence users), it seems likely that more than $2.7 \mathrm{~g}$ of omega- 3 fatty acids could be ingested daily without negative effects.

Subsistence users may also be concerned that despite the benefits from the standpoint of omega-3 fatty acids and other nutrients, high intake of bowhead blubber might cause health problems if contaminant loads are high. This does not appear to be a cause for concern. Hoekstra et al. (2005) assessed persistent organochlorine (OC) contaminants in bowhead whale tissues and found that OC concentrations were lower than those in other marine mammals examined, presumably because of the low trophic level occupied by the bowhead. In addition, Wetzel and colleagues (unpubl. data) have examined bowhead tissues for polycyclic aromatic hydrocarbons (PAHs) and did not find these oil-related contaminants at detectable levels. Both studies concluded that, with respect to the contaminant of concern (OCs or PAHs), consumption of bowhead whale appears to be safe at present. It is possible that other, undocumented lipid-soluble contaminants may exist.

Unalik and maktak represent only two of many common ways in which Inupiat people consume blubber. By definition, both are from superficial sites, since the epidermis is attached. Our limited sampling indicates that all of the superficial umbilical sampling sites appear to be especially nutritious, in terms of omega- 3 fatty acids; in fact, samples taken at all depths at the umbilical ventral (UV) and umbilical lateral (UL) sites contain abundant omega3 fatty acids. As noted above, EPA is found in relatively high amounts in all sample sites, but the distributions of DHA, DPA, and 18:4(n-3) are all skewed heavily toward the umbilical girth sites. Thus, consumers of bowhead blubber are likely to get one of the two most important omega-3 fatty acids (EPA) regardless of the places from which blubber is taken, but will be most likely to get the other nutritionally important omega-3 (DHA) in blubber from sites along the umbilical girth.

The two superficial locations sampled one meter caudal to the blowhole (blowhole lateral [BL] and blowhole ventral $[\mathrm{BV}])$ both contained relatively small amounts of omega-3 fatty acids, but still represent a source of these nutrients. This finding is not surprising in those locations, since the outer blubber layer is relatively lipid poor, compared to the inner and middle blubber layers (Mau, 2004). It is interesting to note that the site with the highest percent composition of omega- 3 fatty acids is BV5.

One might question whether blubber from particular locations and depths is especially sought for its taste, for health, or for other culturally related reasons. In fact, blubber and maktak from the omega-3 rich umbilical girth sites get split in two: half goes to the successful crew members, and the other half is served to the public at a post-harvest celebration at the captain's house (Willetto et al., 2002).

Bowhead whales are huge, reaching lengths approaching $66 \mathrm{ft}(20 \mathrm{~m})$ and weights in excess of 60 tons. The 

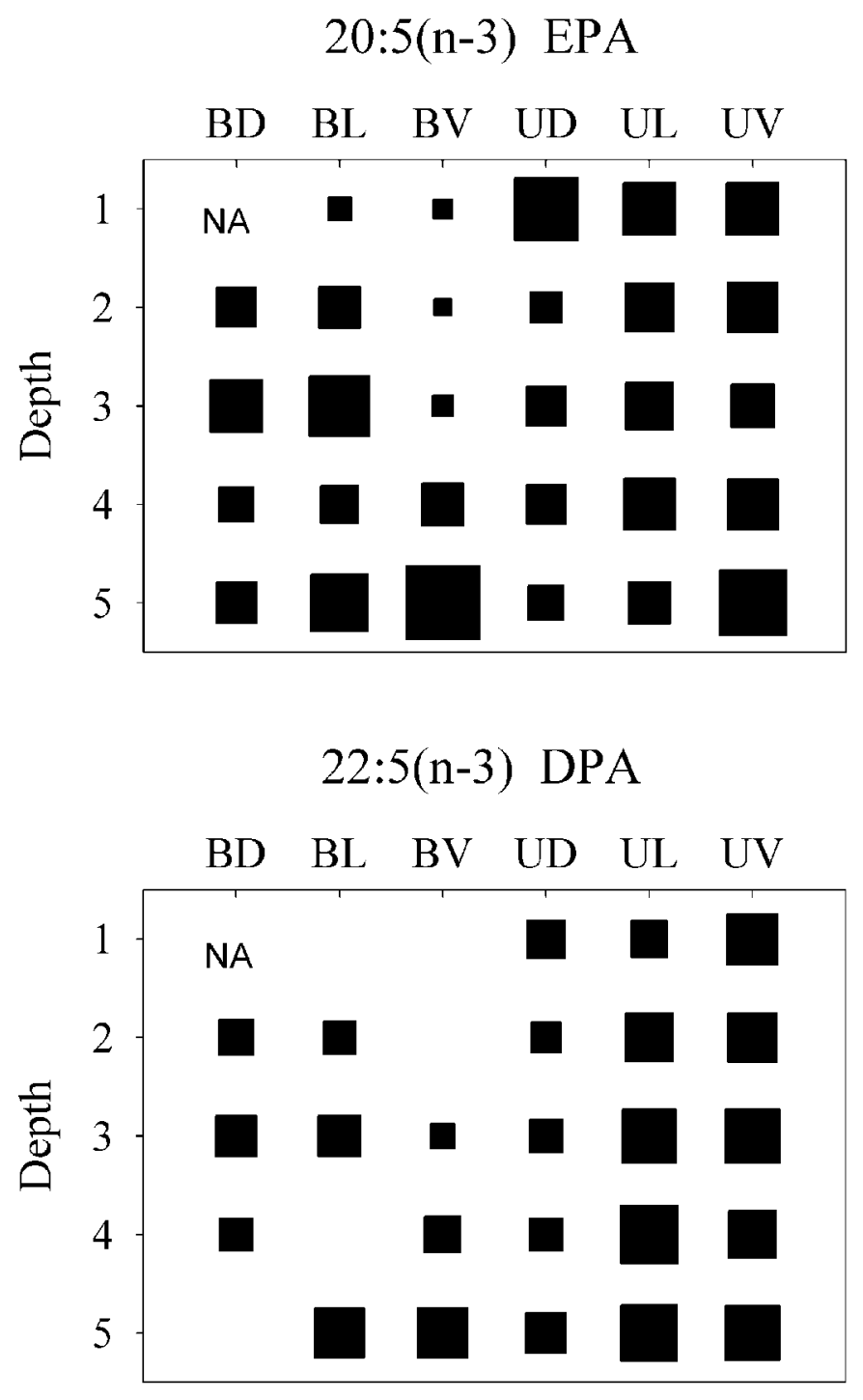

$$
21: 5(n-3)
$$

BD BL BV UD UL UV

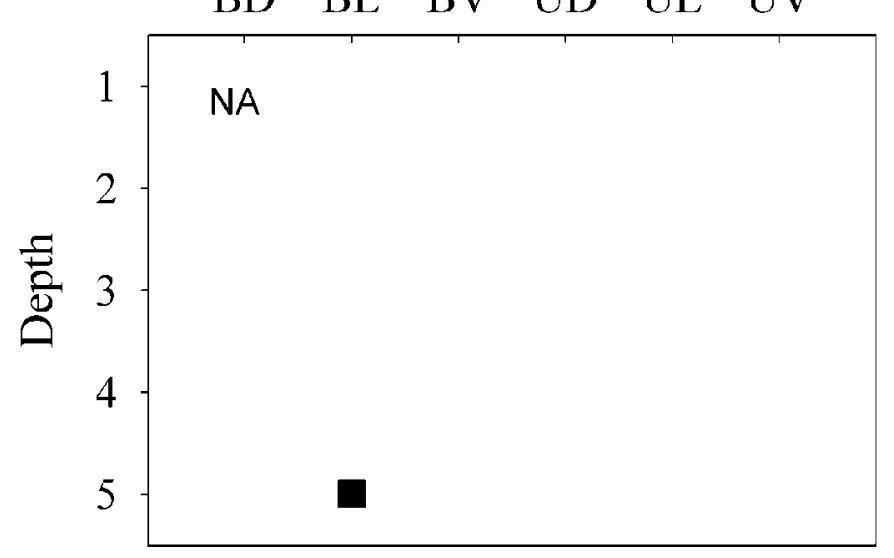

22:6(n-3) DHA

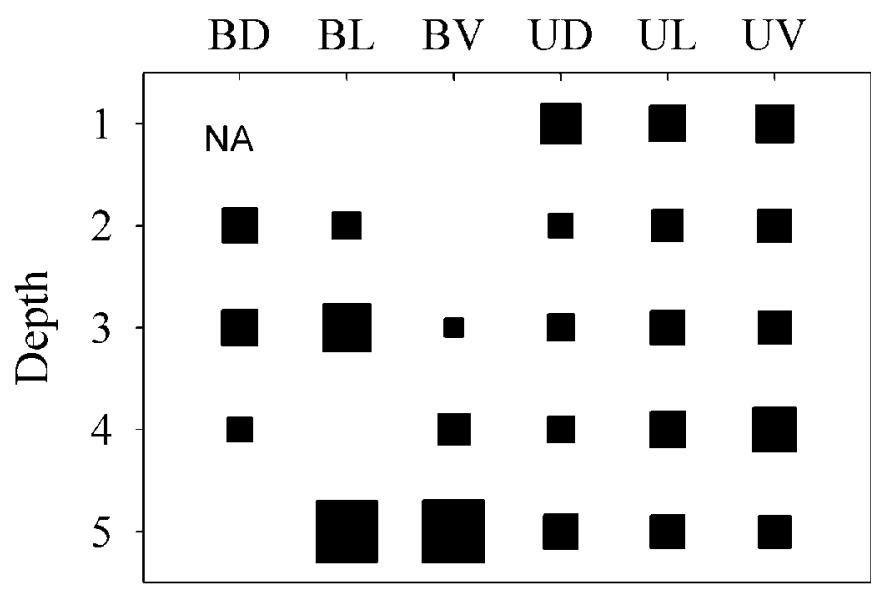

$18: 4(n-3)$

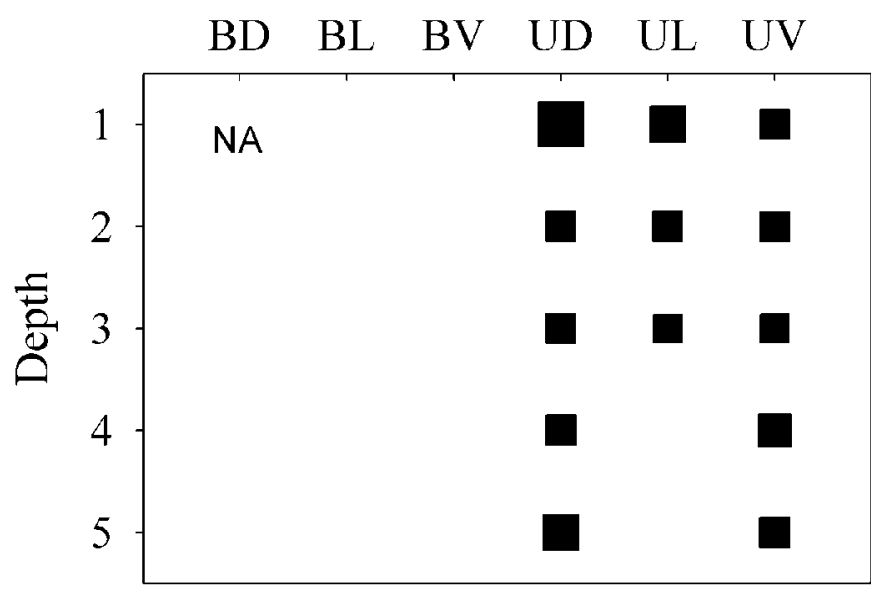

$20: 4(n-6)$

BD BL BV UD UL UV

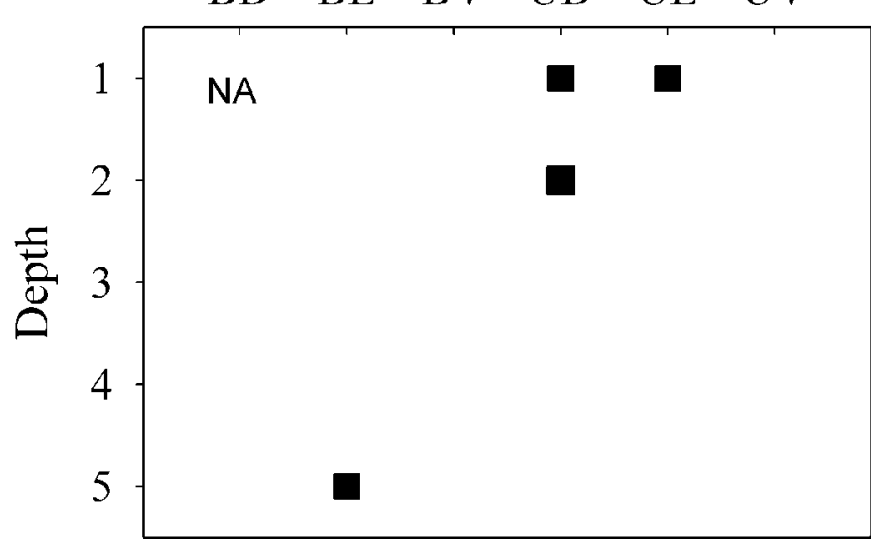

FIG. 3. Relative distribution and abundance of omega- 3 and omega- 6 fatty acids in 29 samples of blubber from a bowhead whale. Depth (Y-axis) refers to the five sampling depths at each sample site, with 1 being most superficial. The letters on the $\mathrm{X}$-axis represent sampling sites where $\mathrm{BD}=$ blowhole dorsal, $\mathrm{BL}=$ blowhole lateral, $\mathrm{BV}=$ blowhole ventral, $\mathrm{UD}=$ umbilical dorsal, $\mathrm{UL}=$ umbilical lateral, and $\mathrm{UV}=$ umbilical ventral. The size of the squares within any particular box indicates the relative abundance of that particular fatty acid among locations. The scale (size of the squares) is not consistent for all fatty acids shown; the actual percent compositions of different fatty acids in each sample are provided in Table 1. 
blubber encasing the body of a whale may be quite thick (38-42 cm [George et al., 2002; Mau, 2004]). Thus, the blubber of a single harvested whale represents an enormous resource for subsistence communities along Alaska's North Slope. In Barrow, 75\% of Inupiat households consume bowhead whale at a rate of $216 \mathrm{~kg}$ per household each year (Huntington et al., 1998).

Muscle tissue (skeletal and cardiac) of bowhead whales, as well as other cetacean species, also contains lipids (O'Hara et al., 2004). Muscle lipid stores may increase seasonally (George et al., 2002). If those stores include the same percentages of omega-3 fatty acids that exist in blubber, consumption of bowhead meat, tongue, and heart would provide a significant source of these nutrients, plus protein and other components of a healthy diet (O'Hara et al., 2004). These tissues may also contain omega- 6 fatty acids, which were notably scarce in blubber.

There are few thorough descriptions of fatty acid constituents of blubber and maktak of bowhead and other whales. Nobmann and her colleagues (e.g., Nobmann et al., 1998, 1999, 2005), who assessed the diet of Siberian Yupiks in Alaska, found that traditional foods such as maktak (or muktuk) contribute to the high omega-3 intake among these people. In fact, the five foods that provided the greatest sources of omega-3 fatty acids in diets of Northwest Alaska Natives were seal oil, salmon, mayonnaise, maktak, and chips, in that order. Nobmann et al. (1999:254) concluded that "consumption of traditional foods is important for maintaining cardiovascular health."

In some marine mammal and fish species, omega-3 fatty acids may represent $15-45 \%$ of all fatty acids present and provide an important source of these nutrients (Malcolm et al., 1996), which has encouraged the Alaska Division of Public Health to support the consumption of traditional foods. Our study documents the importance of bowhead whale blubber as a source of omega-3 fatty acids for some subsistence communities. The harvest of bowhead whales remains controversial (Marine Mammal Commission, 2001), but the bowhead as a traditional food makes sense nutritionally for Alaska Native communities.

\section{ACKNOWLEDGEMENTS}

This study would not have been possible without the assistance and support of whaling captains and crews in Barrow, Alaska. Similarly, Craig George, Benny Akcootchook, and Matt Irinaga of the Department of Wildlife Management of the North Slope Borough (Charles Brower, Director) provided logistical and monetary support essential to acquisition of tissues. Our sincere thanks go to both the whalers and the Borough staff, including Cyd Hanns and Craig George, for comments on the manuscript. We also thank Dr. Cheryl Rosa (University of Alaska Fairbanks) and Dr. Robert Mattlin (Marine Mammal Commission) for assistance with sub-sampling of the blubber; Dr. Teri Rowles and the National Marine Fisheries Service for financial support and advice, as well as for allowing samples to be collected under
Rowles' Permit \# 932-1489-00; Mr. Jay Sprinkel for assistance with statistics and figures; Dr. Lori Verbrugge (Alaska Public Health Department) for her comments on a draft of the manuscript; and Lisa Lynch for assistance with lipid extractions and other laboratory procedures. The illustration of the bowhead whale (Figure 1) is by Pieter Arend Folkens/Alaska Whale Foundation, to whom we are very grateful for permitting its use. The manuscript was greatly improved by comments of Dr. Elizabeth Nobmann and two anonymous reviewers.

\section{REFERENCES}

ARNOLD, S.M., and MIDDAUGH, J.P. 2004. Use of traditional foods in a healthy diet in Alaska: Risks in perspective. 2nd ed. Vol. 2: Mercury. State of Alaska Epidemiology Bulletin 8(11): $1-48$.

BANG, H.O., and DYERBURG, J.1980. Lipid metabolism and ischemic heart disease in Greenland Eskimos. Advances in Nutrition Research 3:1-22.

BANG, H.O., DYERBERG, J., and HJORNE, N. 1976. The composition of food consumed by Eskimos. Acta Medica Scandinavica 200:69-73.

BJERREGAARD, P., YOUNG, T.K., and HEGELE, R.A. 2003. Low incidence of cardiovascular disease among the Inuit: What is the evidence? Atherosclerosis 166:351-357.

BRITISH NUTRITION FOUNDATION. 1992. Unsaturated fatty acids: Nutritional \& physiological significance. The Report of the British Nutrition Foundation's Task Force. London: British Nutrition Foundation.

DESTAILLATS, F., and ANGERS, P. 2002. One-step methodology for the synthesis of FA picolinyl esters from intact lipids. Journal of the American Oil Chemists' Society 79:253-256.

DYERBURG, J. 1989. Coronary heart disease in Greenland Inuit: A paradox. Implications for western diet patterns. Arctic Medical Research 48:47-54.

EATON, S.B., and KONNER, M. 1985. Paleolithic nutrition: A consideration of its nature and current implications. New England Journal of Medicine 312:283-289.

EGELAND, G.M., FEYK, L.A., and MIDDAUGH, J.P. 1998. The use of traditional foods in a healthy diet in Alaska: Risks in perspective. Bulletin No. 6. Anchorage: State of Alaska, Department of Health and Social Sciences, Division of Public Health, Section of Epidemiology.

FDA (U.S. FOOD AND DRUG ADMINISTRATION). 2004. FDA announces qualified health claims for omega-3 fatty acids. FDA News, September 8, 2004.http://www.fda.gov/bbs/topics/news/ 2004/NEW01115.html.

FOLCH, J., LEES, M., and STANLEY, G.H.S. 1957. A simple method for the isolation and purification of total lipids from animal tissues. Journal of Biological Chemistry 226:497-509.

GEORGE, J.C., SUYDAM, R., and O'HARA, T. 2002. Observations on some basic morphometric characters of the bowhead whale. In: Willetto, C.A., O'Hara, T.M., and Rowles, T., eds. Bowhead Whale Health and Physiology Workshop. 1-4 October 2001, Barrow, Alaska. 79-80. 
GUNSTONE, F.D. 1994. Fatty acid structure. In: Gunstone, F.D., Harvey, J.L., and Padley, F.B., eds. The lipid handbook. 2nd ed. London: Chapman and Hall. 1-19.

GUNSTONE, F.D., and HERSLÖF, B.G. 2000. Lipid glossary 2. Bridgwater, England: The Oily Press, P.J. Barnes \& Associates.

GURR, M.I. 1999. Lipids in nutrition and health: A reappraisal. Chapter 4. The nutritional and biological properties of polyunsaturated fatty acids. Bridgwater, England: The Oily Press, P.J. Barnes \& Associates.

HILD, C.A. 2002. Contaminants in Alaska: Is America's Arctic at risk? In: The status of Alaska's oceans \& watersheds in 2002. Anchorage: Exxon Valdez Oil Spill Trustee Council. 95-108.

HOEKSTRA, P.F., O'HARA, T.M., BACKUS, S.M., HANNS, C., and MUIR, D.C.G. 2005. Concentrations of persistent organochlorine contaminants in bowhead whale tissues and other biota from northern Alaska: Implications for human exposure from a subsistence diet. Environmental Research 98:329-340.

HUNTINGTON, H.P., MOSLI, J.M., and SHUSTOV, V.B. 1998. Peoples of the Arctic: Characteristics of human populations relevant to pollution issues. AMAP assessment report: Arctic pollution issues. Oslo: Arctic Monitoring and Assessment Programme. $141-182$.

IVERSON, S.J., FROST, K.J., and LOWRY, L.F. 1997. Fatty acid signatures reveal fine scale structure of foraging distribution of harbor seals and their prey in Prince William Sound, Alaska. Marine Ecology-Progress Series 151:255-271.

KRAUSS, R.M., ECKEL, R.H., HOWARD, B., APPEL, L.J., DANIELS, S.R., DECKELBAUM, M.D., ERDMAN, J.W., Jr., KRIS-ETHERTON, P., GOLDBERG, I.J., KOTCHEN, T.A., LICHTENSTEIN, A.H., MITCH, W.E., MULLIS, R., ROBINSON, K., WYLIE-ROSETT, J., ST. JEOR, S., SUTTIE, J., TRIBBLE, D.L., and BAZZARRE, T.L. 2000. AHA dietary guidelines. Revision 2000: A statement for healthcare professionals from the Nutrition Committee of the American Heart Association. Circulation 102:2284-2299.

KRIS-ETHERTON, P.M., HARRIS, W.S., and APPEL, L.J. 2002. Fish consumption, fish oil, omega-3 fatty acids, and cardiovascular disease. Circulation 106:2747-2757.

LANTING, C.I., FIDLER, V., HUISMAN, M., TOUWEN, B., and BOERSMA, E. 1994. Neurological differences between 9 year old children fed breast milk and formula milk as babies. Lancet 344:1319-1322.

LI, D., BODE, O., DRUMMOND, H., and SINCLAIR, A.J. 2003. Omega-3 (n-3) fatty acids. In: Gunstone, F.D., ed. Lipids for functional foods and nutraceuticals. Bridgwater, England: The Oily Press, P.J. Barnes \& Associates. 225-262.

MACLEAN, C.H., MOJICA, W.A., and MORTON, S.C. 2004. Effects of omega-3 fatty acids on lipids and glycemic control in type II diabetes and the metabolic syndrome and on inflammatory bowel disease, rheumatoid arthritis, renal disease, systemic lupus erythematosus, and osteoporosis: Summary. Evidence Report/Technology Assessment 89. AHRQ Publication Number 04-EO12-1. Rockville, Maryland: Agency for Healthcare Research and Quality.

MALCOM, G.T., BOUDREAU, D.A., and MIDDAUGH, J.P. 1996. Omega-3 fatty acids: Gift from the sea. 10th International
Congress on Circumpolar Health, Anchorage, Alaska, American Society of Circumpolar Health.

MARINE MAMMAL COMMISSION. 2001. Annual Report to Congress 2001. Bethesda, Maryland: Marine Mammal Commission.

MARTINEZ, M., GIL-GIBERNAU, J.J., and BALLABRIGA, A. 1998. Lipids of the developing human retina: I. Total fatty acids, plasmalogens, and fatty acid composition of ethanolamine and choline phosphoglycerides. Journal of Neurobiological Research 20:484-490.

MAU, T.L. 2004. Investigations of the role of lipids in marine mammal diets, health and ecology. PhD Dissertation, Institute of Marine Science, University of Alaska, Fairbanks.

McLAUGHLIN, J.B., MIDDAUGH, J.P., UTERMOHLE, C.J., ASAY, E.D., FENAUGHTY, A.M., and EBERHART-PHILIPS, J.E. 2004. 1979-2002 changing patterns of risk factors and mortality for coronary heart disease among Alaska Natives. Journal of the American Medical Association 291:2545-2546.

NATIONAL ACADEMY OF SCIENCES. 2002. Dietary reference intakes for energy, carbohydrate, fiber, fat, fatty acids, cholesterol, protein, and amino acids (macronutrients). http://nap.edu/ openbook/0309085373/html/.

NOBMANN, E.D., BYERS, T., LANIER, A.P., HANKIN, J.H., and JACKSON, M.Y. 1992. The diet of Alaska Native adults: 1987-1988. American Journal of Clinical Nutrition 55:10241032.

NOBMANN, E.D., EBBESSON, S.O.E., WHITE, R.G., SCHRAER, C.D., LANIER, A.P., and BULKOW, L.R. 1998. Dietary intakes among Siberian Yupiks of Alaska and implications for cardiovascular disease. International Journal of Circumpolar Health 57(1):4-17.

NOBMANN, E.D., EBBESSON, S.O.E., WHITE, R.G., BULKOW, L.R., and SCHRAER, C.D. 1999. Associations between dietary factors and plasma lipids related to cardiovascular disease among Siberian Yupiks of Alaska. International Journal of Circumpolar Health 58:254-271.

NOBMANN, E.D., PONCE, R., MATTIL, C., DEVEREUX, R., DYKE, B., EBBESSON, S.O.E., LASTON, S., MacCLUER, J., ROBBINS, D., ROMENESKO, T., RUOTOLO, G., WENGER, C.R., and HOWARD, B.V. 2005. Dietary intakes vary with age among Eskimo adults of northwest Alaska in the GOCADAN study, 2000-2003. The Journal of Nutrition 135:856-862.

O'HARA, T., MAU, T., YLITALO, G., and CASTELLINI, M. 2001. Comparing analytical techniques for bowhead whale blubber lipid levels: Impact on body condition and contaminants interpretations. Proceedings from the 14th Biennial Conference on the Biology of Marine Mammals, 28 November-3 December 2001, Vancouver, British Columbia. 160. (Abstract only)

O'HARA, T.M., HOEKSTRA, P., HANNS, C., MUIR, D., WETZEL, D., and REYNOLDS, J. 2004. A preliminary assessment of the nutritive value of select tissues from the bowhead whale based on suggested nutrient daily intakes. International Whaling Commission Scientific Committee Report SC/56/E2:1-19.

STORLIEN, L.H., JENKINS, A.B., CHISOLM, D.J., PASCOE, W.S., KHOURI, S., and KRAGEN, E.W. 1991. Influence of dietary fat composition on development of insulin resistance in 
164 • J.E. REYNOLDS, III et al.

rats: Relationship to muscle triglyceride and omega-3 fatty acids in muscle phospholipids. Diabetes 40:280-289.

UK DEPARTMENT OF HEALTH. 1991. Dietary reference values for food energy and nutrients for the United Kingdom. Committee on Medical Aspects of Food Policy Report on Health and Social Subjects No. 41. London: Her Majesty's Stationery Office.

VERBRUGGE, L.A., and MIDDAUGH, J.P. 2004. Use of traditional foods in a healthy diet in Alaska: Risks in Perspective. 2nd ed. Vol. 1: Polychlorinated biphenyls (PCBs) and related compounds. State of Alaska Epidemiology Bulletin 8(8):1-62.
WETZEL, D.L., and REYNOLDS, J.E. 2004. Definitive identification of fatty acid constituents in marine mammal tissues. Canadian Journal of Fisheries and Aquatic Sciences 61:554-560.

WILLETTO, C.E., O'HARA, T.M., and ROWLES, T., eds. 2002. Bowhead Whale Health and Physiology Workshop, 1-4 October 2001, Barrow, Alaska. Barrow: North Slope Borough. 